\title{
$\boldsymbol{\nabla}$ Artikkeli
}

\section{Jotakin uutta, jotakin vanhaa}

\section{Kansalaisten arvioita median toiminnasta ja journalismista vaalirahakohussa}

\begin{abstract}
Viestinnän tutkimuksessa kansalaismielipiteen selvittely mediasta ja journalismista ylipäätään on yleistä, mutta politiikan julkisuudessa kansalaisarvioita näistä kahdesta on tutkittu varsin vähän. Tässä artikkelissa perehdytään kansalaisten agendaan ja pyritään selvittämään, mitä piirteitä mediasta sekä journalismista pidetään hyvinä ja mitä pahoina. Lisäksi tarkastellaan, miten ihmisten suhtautuminen niihin on viime vuosikymmeninä muuttunut. Asiaa tutkitaan vaalirahakohun aikana kerätyillä aineistoilla (kaksi survey-kyselyä, kaksi laajaa internetin keskustelupalsta-aineistoa ja 23 kansalaisen kohusta kirjoittamat päiväkirjat), joita analysoidaan sekä määrällisesti että laadullisesti. Mielipiteiden tarkastelu osoittaa, että kansalaisten suhtautuminen mediaan ja journalismiin vaalirahakohussa on kahtalaista. Yhtäältä paljastusjuttuja kehutaan avoimuuden lisäämisestä, ja median entistä aktiivisempi sekä poliitikkoja haastava ote on muuttunut aiempia tutkimuksia hyväksytymmäksi. Toisaalta journalistien ja vaalirahauutisoinnin nähdään muuttuneen liian henkilöönkäyviksi ja unohtaneen journalismin perinteiset hyveet kuten tasapuolisuuden.
\end{abstract}

AVAINSANAT: politiikka, journalismi, kansalaiset, vaalirahakohu

V

iestinnän tutkimuksessa politiikan julkisuus on perinteisesti määritelty kolmen toimijaryhmän - poliittisen järjestelmän, median ja kansalaisten - vuorovaikutukseksi. Siinä medialla on nähty eräänlaisen väliportaan rooli: media toimii poliittisen järjestelmän valvojana ja sen päätöksistä kertojana sekä tarjoaa kansalaisille kanavan päättäjien suuntaan. (Ks. esim. McNair 2003, 20.) Tässä asetelmassa kiinnostavaksi nousee median agenda suhteessa sekä poliittiseen järjestelmään että kansalaisiin - siis se, millaisen suhteen media luo muiden toimijaryhmien kanssa ja millaisina aihe- ja ilmaisutapavalintoina se ilmenee käytännössä journalismissa (ks. esim. McCombs 2004).'

Suomalaisessa viestinnän tutkimuksessa on selvitetty erityisesti median ja journalismin suhdetta poliittiseen järjestelmään. Viime vuosikymmeninä tälle suhteelle on ollut tyypillistä yhtäältä politiikan raportoinnin keventyminen, henkilöllistymi- 
nen ja viihteellistyminen sekä toisaalta poliitikkojen ja journalistien kasvava vastakkainasettelu (ks. esim. Aula 1991; Moring \& Himmelstein 1993; Kanerva 1994; Isotalus 1998; Ruonala 1998; Holmberg 2004, 242-244; Kantola 2011, 27-28).

Muutos on herättänyt poliitikoissa närää mediaa kohtaan. 1980-luvulla Kalevi Sorsa syytti tiedotusvälineitä "infokratian" luomisesta ja Mauno Koivisto toimittajia "sopuliilmiöstä". Paavo Väyrynen taas arvioi "mediapelin" pudottaneen hänet vuoden 1994 presidentinvaalin toiselta kierrokselta. Uudella vuosituhannella kriitikkojen kirjo on laajentunut. Monet poliitikot ovat aktiivisesti arvostelleet median toimintatapoja ja syyttäneet toimittajia muun muassa ajojahdeista, pintajulkisuuteen keskittymisestä ja moralismista (Alho 2004; Saari 2009; Hakala 2011, 89-114).

Samaan aikaan kansalaismielipiteet median toiminnasta politiikan julkisuudessa ovat saaneet niukasti huomiota tutkijoilta. Muutamissa tehdyissä tutkimuksissa kansalaisten mielipiteiden on havaittu olleen hieman poliitikkojen vastaavia ristiriitaisempia. Vuoden 1994 presidentinvaalikampanjassa toimittajien ehdokkaita haastava tyyli johti siihen, että kansalaiset eivät tunteneet toimittajia edustajikseen (Jääsaari \& Savinen 1995, 54). Saman vuoden EU-kansanäänestyksen raportoinnissa mediaa syytettiin liiallisesta, etäisestä ja puolueellisesta - siis EU-myönteisestä - uutisoinnista (Aula 1996, 294-296; Kivikuru 1996; 335-341; Alastalo 1996, 377-387). Vuosituhannen vaihteessa kansalaiset arvioivat journalismia politiikan avoimuutta ja sananvapautta edistävänä tekijänä, mutta pitivät sen fokusta turhan viihteellisenä, imagoihin keskittyvänä ja poliitikkojen yksityisasioita tonkivana (Koski 2002).

Tällä vuosituhannella kansalaismielipidettä on tutkittu lähinnä mielipidemittauksissa. Niissä suomalaiset ovat arvioineet luottamuksensa mediaan varsin matalaksi muihin yhteiskunnan instituutioihin verrattuna (Borg 2007, 11). Lisäksi kansalaiset ovat todenneet median vallan kasvaneen liian suureksi (Karppinen \& Jääsaari 2007, 7-9; Haavisto \& Kiljunen 2011, 25-26). Mediakriittisyyttä on siis ilmassa, mutta tulosten tarkempi tulkinta on vaikeaa - onhan esimerkiksi median valta olettamuspohjaista ja niin muodoin hyvin hankalasti mitattavissa (E. Väliverronen 2009, 20). Kysymykset usein monoliitiksi kuvatun median yleisestä luotettavuudesta tai vallasta eivät myöskään auta, kun pohditaan, mitä kansalaiset ajattelevat tiedotusvälineiden toiminnasta nimenomaan politiikan julkisuudessa.

Viestinnän tutkimuksen niukkaa huomiota kansalaismielipiteisiin voi selittää suomalaisen politiikan julkisuuden luonteella. Niin sanotun korkean modernin aikana (ks. esim. Kantola 2011, 33-38) järjestelmä oli edellä mainitun McNairin mallin mukaisesti vahvasti hierarkkinen. Media toimi siinä pitkään politiikan kentän jatkeena raportoiden kansalaisille poliitikkojen päätöksistä ja kannanotoista - usein jopa sanatarkasti (J. Väliverronen \& Kunelius 2009). Kansalaiset olivat hierarkiassa alimmaisina. Heidän mielipiteitään noteerattiin tiedotusvälineissä lähinnä vain vaalipäivinä, ja tavan kansalaiselle oman mielipiteen ilmaisukanaviakin oli niukasti. Ajatuksensa pääsi mediassa esittämään lähinnä lehtien yleisönosastoissa - silloinkin toimittajien hyväksyminä ja muokkaamina. (J. Väliverronen 2011, 143-144.)

1980-luvulta alkaen hierarkian rajat ovat kuitenkin liudentuneet. Yhteiskunnalliset ja taloudelliset muutokset ovat johtaneet julkisuuden notkistumiseen ja moniar- 
voistumiseen sekä mediakentän pyrkimyksiin erottautua politiikasta (Kantola 2011a, 39-41). Käytännössä median pyrkimykset oman agendan luomiseksi ovat ilmenneet edellä mainittuina raportointityylin muutoksina ja uutena asennoitumisena politiikkaa kohtaan. Muutoksia pidettiin pitkään lähinnä kosmeettisina. Journalismin todettiin keskittyneen pääosin juttujen muodon ja dramaturgian hallinnointiin (J. Väliverronen \& Kunelius 2009) - tai Entmanin (1993) sanoin asioiden kehystämiseen - mutta asiakysymyksissä se ei juuri poliitikkoja haastanut. Viime vuosina tiedotusvälineet ovat kuitenkin lisänneet vastakkainasetteluja ja alkaneet määrittää myös asia-agendaa, mikä on näkynyt skandaaleissa. Sekä poliitikkojen viranhoitoon että heidän yksityiselämäänsä liittyvien mediakohujen ja skandaalien määrä on lisääntynyt 2000-luvulla runsaasti, ja ne ovat myös aiempaa useammin johtaneet poliitikkojen eroon tehtävistään. (Kantola \& Vesa 2011, 43; ks. myös Juntunen \& E. Väliverronen 2009; Virkkunen 2006.)

Myös median suhde kansalaisiin on kokenut murroksen. 1980-luvulta alkanut mediamarkkinoiden vapautuminen, tarjonnan kasvu ja journalismin koventunut kilpailutilanne ovat pakottaneet mediatalot räätälöimään tuotteitaan entistä tarkemmin eri kohderyhmille, joiden (oletettuihin) tarpeisiin ja mielihaluihin pyritään nykyisin vastaamaan muun muassa erilaisten mediakonseptien ja markkinatutkimuksessa käytettävän RISC-analyysin avulla (ks. esim. Helle 2010; Suhonen 2002). Käytettiinpä sitten näitä työkaluja politiikan journalismissa suoranaisesti tai ei, media joutuu ainakin välillisesti ottamaan huomioon kansalaisten mielenliikkeet agendaansa suunnitellessaan.

1990-luvulta alkanut viestintäteknologian ja erityisesti internetin kehitys taas on taannut sen, että kansalaiset ovat nykyisin ajatuksineen aiempaa näkyvämmin mukana päivittäisessä politiikan julkisuudessa. Kansalaisten verkossa esittämiä mielipiteitä on käytetty journalismissa jo pitkään, ja kansalaiset on myös entistä aktiivisemmin otettu mukaan juttujen tekoon. Politiikan alallakin on tehty erilaisia kansalaisjournalistisia kokeiluja jo useita vuosia (ks. esim. Heikkilä 2001; Ahva 2010), ja äskettäin journalistien ja kansalaisten yhteistyötä on tiivistetty niin sanotuissa avoimen datan juttuprojekteissa vaikkapa toimitusten keräämää vaalikonedataa jatkojalostamalla. ${ }^{2}$

Kansalaisten agenda siis ohjaa median agendaa aiempaa vahvemmin, mutta silti kansalaismielipiteiden tarkastelu politiikan julkisuudessa ei ole saanut viestinnän tutkimuksessa juuri huomiota, mikä tuntuu oudolta. Ensinnäkin se kertoo ihmisten suhteesta mediaan ja journalismiin - ja niin muodoin heidän "julkisesta kytkennästään" (Couldry ym. 2007) politiikkaan - aiempia mielipidetutkimuksia yksityiskohtaisemmin. Toiseksi se tarjoaa vertailukohdan 1990-Iuvun murroskaudella tehtyihin tutkimuksiin. Niiden avulla voidaan paitsi päätellä pitemmän ajan kehityskulkuja kansalaisten agendasta myös hahmotella sitä, millaiseksi heidän suhtautumisensa mediaan ja journalismiin voi jatkossa muotoutua. Asialla on luonnollisesti vaikutuksensa myös politiikan ja median suhteisiin tänä murrosaikana, jolloin journalismin tulevaisuus demokratian edistäjänä on monin paikoin koettu vakavasti uhatuksi (E. Väliverronen 2009, 13; 24-26). 


\section{Tutkimuksen tavoite ja toteutus}

Nämä ajatukset mielessä lähden selvittämään kansalaisten mielipiteitä median toiminnasta politiikan julkisuudessa. Perehdyn asiaan käyttämällä esimerkkitapauksena taannoista vaalirahakohua, joka on kuvaava esimerkki median ja politiikan suhteiden murroksesta. Kohu käynnistyi keväällä 2008 keskustapoliitikko Timo Kallin todettua Ylen A-studiolle, ettei hän ilmoittanut oikeusministeriölle vuoden 2007 eduskuntavaalien rahoitustaan lainmukaisesti, koska rikkomuksesta ei seuraa rangaistusta. Jupakka laajeni nopeasti erilaisiin vaalirahoituksen rakenteellisiin epäkohtiin, ja sitä on arvioitu Suomen poliittisen historian mittavimmaksi skandaaliksi medianäkyvyydellä mitattuna. Asiaa puitiin tiedotusvälineissä intensiivisesti kolmisen vuotta, ja tapahtumat vaikuttivat muun muassa vaalirahoituslainsäädännön kiristymiseen ja monien nimekkäiden poliitikkojen eroon tehtävistään. Median rooli tapahtumien selvittelyssä nähtiin poikkeuksellisen aktiiviseksi. Käänteistä raportoitiin ajoittain niin aggressiivisesti, että se herätti kritiikkiä toimittajakunnassakin. (Kantola ym. 2011, 65-70; 82-85.)

Olettamukseni on, että journalistien toiminta tässä poikkeuksellisessa tapahtumasarjassa on herättänyt myös kansalaiset arvioimaan median ja journalismin nykytilaa politiikan julkisuudessa laajasti ja monipuolisesti. Tutkin tässä yhteydessä kansalaisten ajatuksia niin vaalirahakohun uutisoinnista kuin uutisoijistakin. Tavoitteenani on selvittää, millainen agenda kansalaisilla on median ja journalismin suhteen: millaiseksi kansalaiset niitä arvioivat, mitä he niiltä kaipaavat ja mitä he eivät niiltä hyväksy. Tarkastelu tapahtuu kolmessa aineistossa, jossa kansalaiset ovat voineet arvioida ja kritisoida journalismia sekä mediaa ja sen toimijoita erilaisissa ympäristöissä ja eri vaalirahakohun vaiheissa ${ }^{3}$ :

- Taloustutkimuksen kyselytutkimukset: ensimmäinen teetetty helmi-maaliskuussa $2010(\mathrm{~N}=1057)$ ja toinen tammikuussa $2011(\mathrm{~N}=1164)^{4}$

- Kansalaisten verkkokeskustelut: Iltalehden ja Suomi24:n keskustelupalstoilta Matti Vanhasen lautakasajupakan ${ }^{5}$ ajalta (28.9.-16.12.2009) sekä RAY:n avustusten jakoa koskeneen oikeuskanslerin päätöksen ${ }^{6}$ jälkeiseltä ajalta (16.18.9.2010) kerätyt keskusteluaineistot $\left(\mathrm{N}_{\mathrm{IL}}=375, \mathrm{~N}_{\mathrm{S} 24}=571\right)^{7}$

- Kansalaisten päiväkirjat: Kohti kiinnostavaa journalismia -projektin ${ }^{8}$ yleisöryhmien talvella 2010 kirjoittamat mielipiteet vaalirahakohusta $(\mathrm{N}=23)^{9}$

Aineistojen avulla kansalaisten mielipiteitä on arvioitu sekä määrällisesti (kyselytutkimukset ja verkkokeskustelut) että laadullisesti (verkkokeskustelut ja päiväkirjat). Tavoitteena on ollut saada kyselytutkimusten analyysilla yleiskuva kansalaismielipiteestä ja syventää sitä muiden aineistojen avulla.

\section{Kyselytutkimuksissa mediakriittisiä kansalaisia}

Vaalirahakohu sai runsaasti julkisuutta, ja kansalaiset tarkkailivat sen käänteitä aktiivisesti mediasta. Vain noin kaksi prosenttia kansalaisista kertoi tammikuun 2011 kyse- 
lytutkimuksessa, ettei ollut seurannut tapahtumia lainkaan tiedotusvälineistä. Välineiden suosituimmuusjärjestys oli aiempien tutkimusten kaltainen (ks. esim. Karppinen \& Jääsaari 2007, 6). Ykkösenä oli televisio, jonka kautta noin kolme viidestä seurasi kohua aktiivisesti. Tilattuja sanomalehtiä käytti lähteenään aktiivisesti lähes puolet kansalaisista. Internet oli kolmanneksi yleisin tiedonlähde kohusta lähes 30 prosentin aktiivikäyttäjien osuudellaan. Sitä suosivat erityisesti alle 25 -vuotiaat, kun taas vanhimpien ikäpolvien kulutus painottui vahvasti televisioon ja tilattuihin lehtiin. Myös pienituloisimmilla (alle 10 ooo euroa vuodessa ansaitsevilla) internet oli huomattavasti suositumpi tiedonlähde vaaliraha-asioista kuin muilla tuloryhmillä.

Uutisoinnin tarkempi arviointi eri tiedotusvälineissä kertoo kansalaisten kriittisestä suhtautumisesta. Yksikään tarkastelemistamme tiedotusvälineistä ei saanut kansalaisilta täysin puhtaita papereita vaalirahauutisoinnistaan, ja erityisesti iltapäivälehtien jutut herättivät arvostelua. (Ks. Taulukko 1.) Kun otetaan huomioon, että kansalaiset olivat perehtyneet varsin laajalti median agendaan vaalirahauutisoinnissa, tuloksia voidaan pitää vähintään suuntaa-antavina arvioina eri tiedotusvälineiden uutisoinnista, vaikka niihin vaikuttavat varmasti myös kansalaisten aiemmat mielikuvat eri tiedotusvälineistä.

\begin{tabular}{|l|l|l|l|l|l|l|l|l|}
\hline $\begin{array}{l}\text { Väite } \rightarrow \\
\text { Asennearvio } \downarrow *\end{array}$ & \multicolumn{2}{l|}{$\begin{array}{l}\text { Uutisointi on } \\
\text { sensaatiohakuista. }\end{array}$} & \multicolumn{2}{l|}{$\begin{array}{l}\text { Uutisointi on } \\
\text { puolueetonta. }\end{array}$} & \multicolumn{2}{l|}{$\begin{array}{l}\text { Uutisointi on } \\
\text { luotettavaa. }\end{array}$} & \multicolumn{2}{l|}{$\begin{array}{l}\text { Uutisointi on } \\
\text { kiinnostavaa. }\end{array}$} \\
\hline Tiedotusväline & 2010 & 2011 & 2010 & 2011 & 2010 & 2011 & 2010 & 2011 \\
\hline Televisio & +32 & +24 & +3 & +11 & +27 & +43 & +23 & +30 \\
\hline Tilatut lehdet & +14 & +9 & 0 & +5 & +28 & +36 & +17 & +23 \\
\hline Iltapäivälehdet & +70 & +73 & -40 & -42 & -39 & -35 & -21 & -10 \\
\hline Internet & +30 & +30 & -13 & -10 & -8 & -5 & -1 & -1 \\
\hline
\end{tabular}

* Asennearvio: Väittämää kohtaan esitettyjen myönteisten ja kielteisten arvioiden prosenttiosuuksien erotus. Mitä suurempi positiivinen luku, sitä suurempi osuus kansalaisista on ollut samaa mieltä väitteen kanssa. Negatiiviset luvut merkitsevät vastaavasti kielteistä suhtautumista väitteeseen.

Taulukko 1. Kansalaisten arvioita tiedotusvälineiden vaalirahauutisoinnista vuosina 2010 ja 2011.

Kansalaisten kriittisyys minkä tahansa tiedotusvälineen vaalirahauutisointia kohtaan kasvoi sitä mukaa, mitä enemmän uutisointia oli seurattu. Tämä voi kertoa monestakin asiasta. Ensimmäinen vaihtoehto on, että kansalaiset ovat jatkuvan seurantansa perusteella todenneet uutisoinnin kehnoksi. Toiseksi kyse voi olla "viestintuojan ampuminen" -ilmiöstä: negatiivinen asia saattaa saada ihmiset kokemaan siitä tehdyt uutiset kehnoiksi niiden todellisesta laadusta riippumatta. Kolmanneksi syy arvostelun kasvuun voi piillä kansalaisten saturaatiopisteen saavuttamisessa: kun aiheeseen liittyviä uutisia tulee vastaan jatkuvasti, uutisointi alkaa kyllästyttää, olipa se miten laadukasta tahansa. Tämä saattaa selittää osaltaan sen, miksi kansalaisarviot 
olivat kautta linjan kriittisempiä vuoden 2010 kuin vuoden 2011 kyselyssä. Syksyllä 2009 sattuneet Matti Vanhasen lautakasajupakka, Nuorisosäätiön rahoitusepäselvyydet, Marja Tiuran kiinteistöyhtiö Novalta saamat epäilyttävät tuet ynnä muut tapahtumat olivat herättäneet runsaasti mediahuomiota, kun taas vuoden 2010 lopulla vastaavanlaisia puheenaiheita oli niukasti (ks. Kantola 2011C, 225-226).

Uutisoinnin yksittäisistä ominaisuuksista luotettavuuden arviointi seuraili aiempia tutkimushavaintoja. Kansalaisten luottamus oli suurinta eniten seurattujen välineiden eli television ja tilattujen sanomalehtien uutisointiin. Näillä kahdella kansalaisluottamus oli vahvempaa kuin aiemmissa mittauksissa, joissa on tosin kysytty luottamusta mediaan sinänsä, ei sen uutisointiin. Aiemmissa kyselyissä televisioon on luottanut noin puolet kansalaisista ja lehdistöön vain noin joka kolmas, mitä on selitetty iltapäivä- ja juorulehtien heikon maineen vaikutuksella (Borg 2007, 11; 24). Kyselymme vahvisti tätä arviota. Luottamus iltapäivälehtien uutisointiin oli huomattavan alhainen verrattuna tilattujen lehtien työhön, joskin korkeampi kuin yleinen luottamus iltapäivälehtiin (vrt. Karppinen \& Jääsaari 2007, 11). Internet-uutisoinnin suhteen ihmiset olivat varsin epätietoisia. Hieman alle kolmannes piti verkon uutisia vaalirahakohusta luotettavina, hieman yli kolmannes ei luottanut niihin ja kolmannes ei osannut kertoa kantaansa. Epävarmojen osuus oli verkkouutisoinnin osalta samansuuruinen kaikissa muissakin väittämissä, ja merkittävin syy siihen on internetin vähäinen käyttö vanhemmissa ikäryhmissä.

Muissa yksittäisissä väittämissä kansalaismielipide vaikuttaa paikoin ristiriitaiselta aiempien havaintojen kanssa. Luotettavuus yhdistetään suomalaisessa kontekstissa usein puolueettomaan ja tasapuoliseen raportointiin (ks. esim. Ylen arvoista Jääsaari 2004, 53-54 ${ }^{10}$, mutta kansalaisten mielestä vaalirahakohussa näitä ei välttämättä nähty. Neutraalia uutisointia ei vaalirahakohusta tehnyt kansalaisten mielestä yksikään tutkituista tiedotusvälineistä, vaan kaikkien raportointia pidettiin varsin selvästi sensaatiohakuisena - iltapäivälehtien uutisointia odotetusti huomattavasti muita selvemmin.

Puolueettomuudenkin yhteys luotettavuuteen on kansalaismielipiteen perusteella hieman rapautunut. Internetin ja iltapäivälehtien osalta yhteys näkyy varsin säännönmukaisesti periaatteella "ei luotettavuutta, ei puolueettomuutta". Poikkeuksena ovat vain alle 25-vuotiaat, jotka arvioivat vuonna 2010 internet-uutisoinnin puolueettomaksi ja epäluotettavaksi. Vuotta myöhemmin vastaavaa ei enää havaittu. Television ja tilattujen lehtien osalta päinvastainen - eli luotettavuuden ja puolueettomuuden yhdistelmä - ei näytä toteutuvan. Niiden uutisoinnin puolueettomuudesta ei oltu yhtä varmoja kuin uutisoinnin luotettavuudesta. Erityisesti yli 65-vuotiaat olivat kriittisiä, ja loppuvuoden 2009 uutisoinnin negatiivinen vaikutus oli nähtävissä vuoden 2010 kansalaismielipiteissä kautta linjan.

Kansalaisten tuntemaa uutisoinnin sensaatiohakuisuutta voi selittää osin itse tapahtuman erityisyydellä. Vaalirahakohussa tuotiin julkisuuteen pitkään muhineita vaalirahoituksen rakenteellisia ongelmia (ks. Kantola ym. 2011, 69-70), joiden yhtäkkinen paljastaminen on saattanut synnyttää tunteen sensaatioiden hakemisesta. Osansa oli kuitenkin kiistatta myös politiikan journalismin muutoksilla ja mediakil- 
pailulla. Niiden seurauksena myös aiemmin varsin etäisesti politiikasta raportoineet televisio ja tilatut lehdet astuivat uutisoinnissaan iltapäivälehtien ja internetin tontille. (emts. 82-85)

Uusi uutisointitapa ja sen ongelmat selittävät myös kansalaisten kriittistä suhtautumista television ja tilattujen lehtien puolueettomuuteen. Vaalirahakohussa aktiivisimpia olivat erityisesti Yle sekä Helsingin Sanomat hyvin kriittisellä tyylillään (emts. 72-73). Ne poikkesivat varsin huomattavasti perinteistään (ks. HS:n osalta J. Väliverronen \& Kunelius 2009; Ylen osalta Salokangas 1996, 37-48), mikä lienee herättänyt kansalaisissa epäilyjä puolueettomuuden hylkäämisestä. Tuntemusta lienee korostanut se, että vaalirahakohussa kriittisyys kohdistui varsin voimakkaasti keskustapuolueeseen, jonka edustajia syytettiin usein väärinkäytöksistä. Epäilyt näkyivät erityisesti Keskustan kannattajien arvioissa. He kyseenalaistivat tilattujen lehtien ja television uutisoinnin puolueettomuuden selvästi muiden puolueiden kannattajia useammin.

Vaalirahauutisoinnin kiinnostavuus taas liittyi läheisesti uutisoinnin muista piirteistä tehtyihin arvioihin. Eniten ihmisiä houkuttivat television ja tilattujen lehtien uutiset, kolmantena seurasi internet, ja vähiten ihmisiä kiinnostivat iltapäivälehtien uutiset. Selvimmät ryhmäkohtaiset erot tulivat iästä: alle 35-vuotiaat pitivät vaalirahauutisointia kaikilta osin huomattavasti mielenkiinnottomampana kuin muut ikäryhmät. Todennäköisimmin asiaa selittää aihepiiri. Politiikka ei perinteisesti ole kiinnostanut nuoria vanhempien ikäryhmien tapaan (Grönlund ym. 2005, 89-90). Kun vielä nuorten tiedot politiikasta ovat myös vähäisemmät kuin vanhemmilla ikäryhmillä (Grönlund 2009, 182; Rapeli 2010, 122), ei ole yllätys, että aiheesta uutisointi ei herätä nuorissa kiinnostusta.

Kiinnostuksen asteen määrityksessä syntyi pientä ristiriitaisuutta. Vaikka kansalaiset arvioivat iltapäivälehtien vaalirahauutisoinnin selvästi sensaatiohakuiseksi, puolueelliseksi ja epäluotettavaksi, uutisointia ei silti pidetty niin epäkiinnostavana kuin olisi voinut luulla. Samaa piirrettä on nähtävissä myös verkkouutisista tehdyissä arvioinneissa. Tätä voi selittää yhteiskunnallisella muutoksella. Julkisuuden notkistuttua uutisoinnin kiinnostavuus määrittyy yhä vähemmän "ylhäältä määritettyjen" asioiden ja yleisen edun pohjalta (vrt. Kantola 2011a, 19-20; 24-25; Kantola 2011b, 118; Hakala 2011, 91) ja yhä enemmän kansalaisten omien intressien pohjalta. Tällöin kiinnostavuus muuttuu aiempaa monitulkintaisemmaksi käsitteeksi: se voi tarkoittaa vaikkapa keskustelua herättävää tai elämyksiä tarjoavaa juttua tai tarinaa kiinnostavasta henkilöstä. Tässä tilanteessa iltapäivälehtien ja verkkouutisten odotettua parempaa arviota voi selittää sillä, että niille ihmisten huomion ja kiinnostuksen herättäminen on jo niiden toimintamallienkin vuoksi arkipäiväistä.

\section{Kansalaiskommenteissa journalismin rajojen pohdintaa}

Kansalaisten keskustelupalstakommentit ja päiväkirjamerkinnät tarkentavat kyselyissä syntynyttä kuvaa ja tuovat esiin myös jonkinasteista ajattelutavan muutosta. Kansalaisten agendan muuttuminen näkyy parhaiten perussuhtautumisessa median 
toimintaan. Vaikka vaalirahauutisointi sai kyselyissä osakseen runsaasti kritiikkiä, esimerkiksi päiväkirjamerkinnöistä hieman yli puolessa mediaa kiiteltiin vaalirahoitusongelmien aktiivisesta esiintuonnista. Koko keskustelupalsta-aineistossa taas journalisteihin tai journalismiin kohdistunutta ensisijaista kritiikkiä oli $14 \%$, eli vain alle neljännes poliitikkoihin kohdistuneesta arvostelusta. Lisäksi keskustelupalstoilla uuden ärhäkkään uutisointitavan koettiin usein tuoneen juttuihin lisävääntöä, joka lisäsi aiheen kiinnostavuutta.

Vaikka sekä Iltalehden että Suomi24:n palstojen keskivertokävijä onkin alle 45-vuotias ", kyse ei ole vain nuorten parissa tapahtuneesta murroksesta, vaan aktiivinen journalismi sai kannatusta myös iäkkäämmiltä päiväkirjan kirjoittajilta. Kansalaisten muuttuneista vaatimuksista kertoo sekin, että varsin usein kommenteissa mainittiin kehujen yhteydessä, että media ei aiemmin ole kyseenalaistanut riittävän hanakasti poliitikkojen toimintaa.

\section{Media toimii vihdoinkin kuten sen pitääkin. Politiikan saasta on kaivettava esiin} keinoja kaihtamatta. (Suomi24)

Vaalirahakohun aikana on huomannut, että median tehtävä neljäntenä valtiomahtina voi joskus jopa toimia. (päiväkirja)

Näyttää siis siltä, että Kosken (2002) havaitsema median ja journalismin aktiivisen toiminnan arvostus on tullut jäädäkseen kansalaismielipiteeseen. Aktiivisen ja haastavan otteen rajoista käytiin kuitenkin vaalirahakohun yhteydessä neuvottelua, mikä kävi ilmi ristiriitaisista kansalaisarvioista. Päiväkirjan kirjoittajista hieman yli joka kolmas piti uutisointia samaan aikaan kiinnostavana ja tavalla tai toisella ärsyttävänä. Vaikka aihetta pidettiin tärkeänä, närkästystä aiheutti edellä mainittu kyltyminen uutisoinnin liialliseen volyymiin, jonka koettiin vieneen tilaa tärkeämmiltä aiheilta.

Keskustelupalstoilla ylitarjontaa ei pidetty suurena ongelmana. Tähän vaikuttaa ainakin se, että niillä vastaajat miettivät asioita huomattavasti lyhyemmällä aikajänteellä kuin päiväkirjoissa. Niinpä kansalaisten kommentointi jäi palstoilla yleensä oman senhetkisen mielipiteen esiintuonniksi - pitempään kestänyttä vuoropuhelua teemoista syntyi harvemmin (vrt. Pietilä 2002) - ja median esiin nostamien päiväkohtaisten teemojen käsittelyksi. Suomi24:n media- tai journalismikritiikkiä sisältäneistä ketjuista $45 \%$ alkoi joko linkillä tuoreeseen juttuun, suoralla lainauksella jutusta tai kirjoittajan referoinnilla siitä. Lukuun sisältyvät vain ketjut, joissa aloittaja on tehnyt eksplisiittisen viittauksen johonkin tiedotusvälineeseen; lisäksi ilman viittausta tehtyjä, mutta päivittäisuutisoinnin pohjalta syntyneitä ketjuja oli huomattava määrä. Tässä mielessä siis kansalaisten arviointi journalismista tapahtuu vahvasti median määrittelemän agendan pohjalta (vrt. Heikkilä ym. 2010, 13).

Päiväkohtaisen uutisoinnin pohjaltakin palstoille riitti lukuisia valituksen aiheita mediasta, vaikka perussuhtautuminen olikin positiivista (ks. Taulukko 2). Tämä kertoo keskustelupalstoille tyypillisestä tilanteesta: keskustelu hajaantuu usein moniksi pieniksi puroiksi. 


\begin{tabular}{|l|l|l|l|}
\hline Kansalaisten journalismikritiikin kohde & Suomi24 (\%) & Iltalehti (\%) & Yhteensä (\%) \\
\hline Totuudellisuuden rikkominen & 21 & 27 & 24 \\
\hline Riippumattomuuden rikkominen & 23 & 18 & 21 \\
\hline Puolueiden äänitorvena olo & 13 & 11 & 13 \\
\hline Poliitikkojen ym. äänitorvena olo & 3 & 4 & 4 \\
\hline Muu riippumattomuusrike (esim. ylikaupallisuus) & 6 & 3 & 5 \\
\hline Neutraalisuuden rikkominen & 33 & 23 & 29 \\
\hline Journalismin politikointi & 19 & 13 & 16 \\
\hline Sensaatiohakuisuus & 10 & 6 & 8 \\
\hline Uutisten neutraalisuuskäytäntöjen rikkominen & 4 & 5 & 4 \\
\hline Luotettavuuden / uskottavuuden vaarantaminen & 10 & 12 & 11 \\
\hline Muu arvostelu & 13 & 19 & 15 \\
\hline Henkilöön kohdistuva kritiikki & 6 & 9 & 7 \\
\hline Kritiikki, joka ei lukeudu em. ryhmiin & 5 & 7 & 6 \\
\hline Kritiikki, kohde epäselvä & 3 & 3 & 3 \\
\hline Yhteensä (\%) * & 100 & 100 & 100 \\
\hline Kommenttien n & 571 & 375 & 946 \\
\hline
\end{tabular}

* Pyöristämisen takia alaluokkien summa ei aina täsmää yläluokan prosenttiosuuden kanssa. Samasta syystä kaikkien prosenttiosuuksien summa ei aina ole 100.

Taulukko 2. Kansalaisten ensisijainen kritiikki journalismia kohtaan Suomi24:n ja Iltalehden keskustelupalstoilla.

Arviot täydentävät kyselytutkimusten tuloksia. Journalismia ja toimittajia syytettiin keskustelupalstoilla ennen muuta perinteisten arvojen - puolueettomuuden, totuudellisuuden ja tasapuolisuuden - rikkomisesta. Tämä kritiikki kumpusi lähinnä Keskustaan ja Matti Vanhaseen vahvasti kohdistuneesta uutisoinnista. Monet arvioivat raportoinnin sisältäneen liiallisia yksinkertaistuksia, tiedon pimitystä ja jopa suoranaisia valheita. Samalla he totesivat nykykatsannossa epämääräisten vaalirahojen vastaanoton olleen pitkään "maan tapa" poliitikkojen keskuudessa ja inmettelivät, miksei muiden kuin Vanhasen tai Keskustan vastaavaa toimintaa juuri noteerattu. Tähän kummasteluun liittyi usein arvioita tai epäilyjä journalistikunnan vasemmistolaisuudesta tai vasemmistosympatioista.

Osin samat toimittajat, jotka eivät vuosikymmeniin huomanneet mitään esim. vasemmistolle kulkeneista rahasalkuista niin idän kuin lännenkin rajojen yli, ovatkin nyt yhtäkkiä muuttuneet "rohkeiksi ja totuudenhaluisiksi". Epäuskottavaa, valikoivaa moraalia ja "totuuden etsintää". He ovat mm. ottaneet oikeudekseen tuomita samasta rötöksestä yhden, mutta päästää muut tietoisesti vapaaksi. (Suomi24) 
Suurimman osan vasemmistolaisuusarvostelusta sai Yle, joka keräsi muutenkin valtaosan yksilöidystä mediakritiikistä (ks. Taulukko 3) - tarkalleen ottaen lähes kolme viidesosaa, jos mukaan lasketaan sekä instituution että sen yksittäisten toimittajien saama kritiikki. Yhtiön toimintaa arvosteltiin tiukimmillaan vasemmiston yritykseksi kaataa istuva hallitus "jäsenkirjatoimittajiensa" avulla. Tällaista Ylen poliittisen vallan tavoitteluksi luokiteltua arvostelua oli 5 \% kaikesta journalismin saamasta kritiikistä; muiden tahojen valtapyrkimysten kritisointi oli selvästi tätä harvinaisempaa. Yksittäisistä toimittajista ja toimituksista erityisesti Silminnäkijä-ohjelmasta vastanneet journalistit sekä Ylen toimitusjohtaja Mikael Jungner joutuivat kansan arvostelun kohteiksi. Muun kritiikin lisäksi heihin kohdistui valtaosa harvoista erovaatimuksista.

\begin{tabular}{|l|l|l|}
\hline Eniten kritisoidut journalismin edustajat & Kriittisten viestien määrä & Osuus kritiikistä (\%) \\
\hline Yle & 371 & 39 \\
\hline Toimittajat / media yleensä & 226 & 24 \\
\hline Mikael Jungner & 37 & 4 \\
\hline Ari Korvola & 33 & 3 \\
\hline Ylen vasemmistolaistoimittajat & 28 & 3 \\
\hline Kritiikkiä yhteensä & 946 & 100 \\
\hline
\end{tabular}

Taulukko 3. Keskustelupalsta-aineiston viisi kritisoiduinta journalismin edustajaa.

Toinen huomattava kansalaiskritiikin kärki keskustelupalstoilla kohdistui uutisoinnin sensaatiohakuisuuteen, jota pidettiin kaupallisuuden aiheuttamana yleisenä median kehityssuuntana. Monet kirjoittajat kokivat luottamuksensa mediaan heikentyneen juuri sensaatiohakuisen raportoinnin vuoksi. Usea myös ilmaisi kommenteissaan, että tämänkaltaisella tyylillä voi olla huolestuttavia seurauksia tulevaisuudessa niin journalismille kuin demokratialle. Sama teema herätti huomiota myös päiväkirjan kirjoittajissa, joissa uutisoinnin sensaatiohakuisuus synnytti ylitarjonnan jälkeen toiseksi eniten kritiikkiä. Asiaa pohtineista valtaosa ehdotti ratkaisuksi vaalirahauutisoinnissa nähtyihin ongelmiin eräänlaista paluuta vanhaan. Heidän mielestään journalismin tulisi unohtaa liiallinen kohujen nostatus ja keskittyä sen sijaan asioiden esiin nostamiseen.

Media kaipaisi nyt hieman sisäistä pohdintaa siitä, mikä on journalismin tehtävä sananvapaudessa, koska jos se on joka lehdellä lukijamäärien ja mainostulojen maksimointi, niin maailmankuvasta tulee aika sensaatiovoittoinen ja hyvin yksipuolinen, kun koko lehdistö ja tv-kanavat päälle toistavat toinen toistensa paljastuksia kuin kuorolauluna eikä muita uutisia ole olemassa, kun media katsoo, ettei niillä saa tarpeeksi lukijoita mainostulojen vastineeksi. (Suomi24) 
Uskon vaalirahakohun vahvistaneen niiden henkilöiden mielipidettä, joita politiikka ei muutenkaan kiinnosta. He saivat vahvistuksen "tiedolleen", että poliitikot huijaavat ja tavoittelevat vain omaa etuaan ja että Kepu pettää aina. (...) Pahin kohun seuraus on se, että tällä hetkellä monella kansalaisella on "tieto" tai ainakin mielikuva, että vaalikampanjan rahoittaminen on laitonta tai ainakin moraalitonta. (päiväkirja)

\section{Yhteenvetoa ja keskustelua}

Kansalaisarviot vaalirahakohun ajalta osoittavat, että vaikka poliittinen julkisuus on muuttunut, sen työnjaossa kansalaisten ja median sekä journalismin välillä näyttävät edelleen monelta osin pätevän vanhat säännöt. Kansalaisten arviot mediasta ja journalismista ovat hyvin pitkälti reaktioita median agendoihin, eikä heidän journalismia haastavasta toiminnastaan vielä juuri näkynyt merkkejä aineistoissa. Esimerkiksi viittauksia kansalaisjournalismiin - vaikkapa kansalaisten median toiminnasta tekemiin blogeihin - oli hyvin harvassa, eikä vaihtoehtoisia avauksia journalismin esiin nostamiin aiheisiin juuri kommenteissa tai keskusteluissa nähty. Kansalaisten agenda mediaa kohtaan vaikuttaa siis pohjimmiltaan yleisödemokratiasta (ks. Manin 1997) tutulta: he arvioivat journalismin tuotoksia nimenomaan yleisöinä.

Tuotosten arvioissa on kuitenkin havaittavissa pientä muutosta aiempaan. Journalismin aktiivinen raportointityyli ja lisääntyvät eronteot poliittisen järjestelmän kanssa näyttävät saaneen kansalaisilta aiempaa laajemman hyväksynnän. Havainto antaa tukea Hallinin ja Mancinin (2004) arviolle, jossa povattiin suomalaisen journalismin muuttuvan konsensushenkisestä demokraattis-korporatistisesta tyylistä liberaalimmaksi. Vanhat perinteetkin näkyivät kuitenkin yhä vaalirahakohun yhteydessä. Kosken (2002) tutkimuksen tapaan kansalaiset karsastivat turhan mielikuvapainotteista uutisointia ja vaativat journalismilta neutraalia raportointia sekä asialähtöisyyttä.

Monien kansalaisten haaveissa oli siis journalismi, joka yhdistäisi demokraattiskorporatistisen ja liberaalin perinteen hyvinä pidetyt puolet. Nämä toiveet muistuttivat suuresti Hallinin (1992) kuvailemaa korkean modernin journalismia, jonka kulta-aika oli 1970-luvulla Yhdysvalloissa. Sen kaltaisen journalismin toteuttamiseen Suomessa ei nykyisessä kaupallistuneessa mediaympäristössä kuitenkaan nähty mahdollisuuksia. Kun vaalirahakohun yhteydessä uutisointiin ei löytynyt sopivaa tasapainoa, päällimmäiseksi kansalaiskuvaksi aineistoista jäi hienoinen pessimismi journalismin nykymenosta ja sen kyvystä innostaa ihmisiä aktiiviseen kansalaisuuteen - siis journalismin kyvystä vahvistaa ihmisten "julkista kytkentää" (Couldry ym. 2007). Huoli ei ollut täysin aiheeton: kevään 2011 eduskuntavaalien jälkeen tehdyssä tutkimuksessa havaittiin, että vaalirahakohun seuraaminen tiedotusvälineistä ei ainakaan nostanut kansalaisten äänestysaktiivisuutta (Mattila \& Sundberg 2012, 237).

Journalismiin kohdistuu siis kansalaisilta muutospainetta, joka on linjassa politiikan julkisuuden murroksen kanssa. Imagoita, henkilöitä ja mediajulkisuutta korostaneelta yleisödemokratialta on valtaamassa alaa konvergenssikulttuuri, jossa pää- 
huomion saavat asiakysymykset, avoimuus ja vuorovaikutus. (Herkman 2012, 122.) Toimittajien ja politiikan suhteissa tämä murros näkyi jo vaalirahakohussa. Tapausta pidetään sukupolvikokemuksena, jonka avulla nuoret toimittajat - ja journalismi laajemminkin - asemoivat itsensä uudelleen suhteessa poliittiseen järjestelmään (Kantola ym. 2011, 83). Tutkimieni aineistojen mukaan samanlaista murrosta ei tapahtunut kansalaisten ja journalismin välillä, vaikka uuden kulttuurin elementtejä journalismilta jossain määrin jo kaivattiinkin. Niiden kysyntä ei kuitenkaan vähene internetin yhteisölliseen kulttuuriin kasvaneiden määrän lisääntyessä, joten poliittisen julkisuuden tutkimuksen kannalta aiheen selvittely jatkossakin on ensiarvoisen tärkeää.

\section{Viitteet}

Medialla tarkoitan tässä artikkelissa tiedotusvälineitä ja journalismilla median tuottamia sisältöjä. Ks. Mäkinen, Esa (12.4.2011). 15 uusiokäyttöä HS:n vaalikonedatalle - viikossa. HS Next. Saatavilla: http://blogit.hs.fi/hsnext/15-uusiokayttoa-hsn-vaalikonedatalle-viikossa (luettu 9.1.2012).

3 Aineistot on kerätty alun perin Helsingin Sanomain Säätiön rahoittamaan tutkimusprojektiin Vaalirahakriisi: median ja politiikan suhteet murroksessa? Projekti toteutettiin yhteistyössä Helsingin ja Tampereen yliopistojen kesken, ja sen tuloksena syntyi keväällä 2011 Anu Kantolan toimittama kirja Hetken hallitsijat: julkinen elämä notkeassa yhteiskunnassa (Gaudeamus).

4 Kyselyt toteutettiin internet-paneelitutkimuksina, ja otokset ovat koko Suomen aikuisväestöä edustavia Ahvenanmaa pois lukien. Tutkimusten virhemarginaali on 3 prosenttiyksikköä suuntaansa 95 prosentin luottamustasolla. Kyselyssä selvitettiin kansalaisten mielipiteitä politiikasta ja journalismista. Tässä artikkelissa keskitytään journalismia koskeviin mielipiteisiin.

5 Lautakasajupakka käynnistyi 28.9.2009 Yle TV2:n Silminnäkijä-ohjelman väitteestä, että Vanhanen oli saanut Nurmijärvelle vuonna 1996 valmistuneeseen taloonsa ilmaisia rakennustarvikkeita nimeltä mainitsemattomalta rakennusyritykseltä. Ohjelmassa käytetyn nimettömän lähteen mukaan sama yritys oli urakoinut taloja myös keskustapuoluetta lähellä olevalle Nuorisosäätiölle, jonka hallituksen puheenjohtaja Vanhanen tuolloin oli. Vanhanen kiisti väitteet ja vaati Yleä paljastamaan, mistä laudoista oli kyse. Yle ei reagoinut vaatimuksiin. Keskusrikospoliisikin selvitti asiaa, mutta esitutkintaa ei aloitettu, koska mahdollisen rikoksen todettiin jo vanhentuneen. Silminnäkijän väitteitä selvitettiin vielä 10.12.2009 Julkisen sanan neuvostossa, joka antoi Ylelle vapauttavan päätöksen äänestyksen jälkeen. Päätöksestä eri mieltä ollut JSN:n puheenjohtaja Pekka Hyvärinen erosi tehtävästään.

6 Oikeuskansleri Jaakko Jonkka teki 16.9.2010 eduskunnan perustuslakivaliokunnalle ilmoituksen, jonka mukaan Vanhasen virkatoimet Raha-automaattiyhdistyksen avustusten jaossa Nuorisosäätiölle tulisi tutkia rikosoikeudellisesti. Jonkan mukaan Vanhasen olisi tullut jäävätä itsensä asian käsittelystä valtioneuvoston yleisistunnoissa. KRP kuulusteli Vanhasta asiasta, mutta tapaus ei johtanut syytteeseen.

$7 \quad$ Iltalehti ja Suomi24 valittiin aineistoiksi valtamedian ja niin sanotun vapaan verkon suosituimpina keskustelupalstoina. Ensimmäisen aineistoerän keruu aloitettiin Silminnäkijä-ohjelman lähetyspäivästä ja päätettiin viikkoa JSN:n päätöksen julkaisun jälkeen. Toinen erä kerättiin kolmen päivän ajalta oikeuskansleri Jonkan ilmoituksesta perustuslakivaliokunnalle. Molemmissa aineistoissa hakusanoina olivat "vaaliraha" ja "vaalirahakohu", ja mukaan analyysiin kelpuutettiin aihepiiristä riippumatta kaikki keskusteluketjut, joissa vähintään toinen hakusanoista esiintyi. Lisäksi Iltalehdestä otettiin mukaan vain toimituksen käynnistämät keskustelut, jotta voitaisiin tutkia kansalaisten ja toimittajien käynnistämien keskustelujen mahdollisia tyylieroja. Koko aineisto oli 8638 viestin laajuinen (IL 2391 viestiä ja Suomi24 6247), ja viestejä analysoitiin niiden sisältämän ensisijaisen kritiikin perusteella. Tässä artikkelissa aineistosta käsitellään vain ensisijaisesti journalismiin kohdistunutta arvostelua (946 viestiä), ellei toisin mainita. 
9 Osallistujat olivat eri-ikäisiä ja eri ammateissa toimivia pirkanmaalaisia ja keskisuomalaisia, joita pyydettiin kirjoittamaan vapaamuotoisesti huomioitaan ja mielipiteitään vaalirahakohusta. Halutessaan he saivat käyttää tekstin jäsentelyssä apunaan heille annettua kysymyslomaketta. Osallistujista 12 oli miehiä ja 11 naisia. Miesten iät vaihtelivat 22 vuodesta 73 vuoteen (keski-ikä 48 vuotta) ja naisten iät 29 vuodesta 65 vuoteen (keski-ikä 46 vuotta).

10 Ks. myös Ylen strategia 2012-2014: http://avoinyle.fi/www/fi/arvot_ja_strategia/ylen_strategia. php (sivulla käyty 26.3.2012).

11 Suomi24:n keskustelupalstan kävijöistä noin kaksi kolmasosaa on alle 45-vuotiaita, ja Iltalehden koko palvelun käyttäjistä samaan ikäryhmään kuuluu hieman yli puolet. Ks. http://www.suomi24. fi/mainonta/tilastot ja http://skuuppi.iltalehti.fi/images/uploads/Yhteenveto-Iltalehti.pdf (sivuilla käyty 26.3.2012).

\section{Kirjallisuus}

Ahva, Laura (2010). Making news with citizens. Public journalism and professional reflexivity in Finnish newspapers. Tampere: Tampere University Press.

Alastalo, Marja (1996). "Kyllähän siitä hirveesti voidaan kirjoittaa, mutta..." Kunnon kansalaisen mediakritiikki. Teoksessa: Kivikuru, Ullamaija (toim.). Kansa euromyllyssä. Helsinki: Helsinki University Press, 365-392.

Alho, Arja (2004). Silent democracy, noisy media. Helsinki: Helsinki University Press.

Aula, Maria Kaisa (1991). Poliitikkojen ja toimittajien suhteet murroksessa? Tutkimus Yleisradion politiikan toimittajien ammatti-identiteetistä 1980-luvulla. Tutkimusraportti 5/1991. Helsinki: Yleisradio.

Aula, Pekka (1996). Mediasta verkkoihin, detaljeista metateemoihin. Kansalaisten mediakäsitykset ja viestintäverkot. Teoksessa: Kivikuru, Ullamaija (toim.). Kansa euromyllyssä. Helsinki: Helsinki University Press, 292-321.

Borg, Sami (2007). Suomalaisten luottamus yhteiskunnallisiin instituutioihin. Teoksessa: Borg, Sami; Ketola, Kimmo; Kääriäinen, Kimmo; Niemelä, Kati \& Suhonen, Pertti. Uskonto, arvo ja instituutiot. Suomalaiset World Values -tutkimuksissa 1981-2005. Yhteiskuntatieteellisen tietoarkiston julkaisuja 4. Tampere: Yhteiskuntatieteellinen tietoarkisto, 9-25.

Couldry, Nick; Livingstone, Sofia \& Markham, Tim (2007). Media consumption and public intellect. Beyond the presumption of attention. Basingstoke: Intellect.

Entman, Robert (1993). Framing: toward clarification of a fractured paradigm. Journal of Communication 43: 4, 51-58.

Grönlund, Kimmo (2009). Poliittinen tietämys. Teoksessa: Borg, Sami \& Paloheimo, Heikki (toim.). Vaalit yleisödemokratiassa. Tampere: Tampere University Press, 175-205.

Grönlund, Kimmo; Paloheimo, Heikki \& Sundberg, Jan (2005). Kiinnittyminen politiikkaan. Teoksessa: Paloheimo, Heikki (toim.). Vaalit ja demokratia Suomessa. Helsinki: WSOY, 88-118.

Haavisto, Ilkka \& Kiljunen, Pentti (2011). Maailman paras maa. EVAn kansallinen arvo- ja asennetutkimus 2011. Helsinki: Taloustieto. Saatavilla: http://www.eva.fi/wp-content/uploads/2011/o3/Maailmanparas-maa.pdf (luettu 8.1.2012).

Hakala, Salli (2011). Notkistuva politiikka. Teoksessa: Kantola, Anu (toim.). Hetken hallitsijat: Julkinen elämä notkeassa yhteiskunnassa. Helsinki: Gaudeamus, 89-114.

Hallin, Daniel C. (1992). The passing of the "high modernism" of American journalism. Journal of Communication 42: 3, 14-25.

Hallin, Daniel C. \& Mancini, Paolo (2004). Comparing media systems. Three models of media and politics. Cambridge: Cambridge University Press.

Heikkilä, Heikki (2001). Ohut ja vankka journalismi. Kansalaisuus suomalaisen uutisjournalismin käytännöissä 1990-luvulla. Tampere: Tampere University Press.

Heikkilä, Heikki; Ahva, Laura; Autio, Hanna; Siljamäki, Jaana \& Valtonen, Sanna (2010). A long and winding road: Quest for partnership from the perspective of "audience". Paper for RIPE@2010 Conference: Public Service Media after the Recession, September 8-11, 2010, London. Saatavilla: http://www.uta.fi/laitokset/tiedotus/jourtutkimus/kiinnostava/RIPE2010_Heikkil\%e4_et_al.pdf (luettu 11.1.2012). 
Helle, Merja (2010). Toimitustyö muutoksessa. Toiminnan teoria ja mediakonseptin käsite tutkimuksen ja kehittämisen kehyksenä. Tampere: Tampere University Press.

Herkman, Juha (2012). Mediasukupolvet ja politiikan julkisuus. Teoksessa: Karppinen, Kari \& Matikainen, Janne (toim.). Julkisuus ja demokratia. Tampere: Vastapaino, 109-132.

Holmberg, Jukka (2004). Etusivun politiikkaa. Yhteiskunnallisten toimijoiden representointi suomalaisissa sanomalehtiuutisissa 1987-2003. Jyväskylä Studies in Humanities 30. Jyväskylä: Jyväskylän yliopisto.

Isotalus, Pekka (toim.) (1998). Kaveri vai peluri: Poliitikko mediassa. Jyväskylä: Atena.

Juntunen, Laura \& Väliverronen, Esa (2009). Intiimin politiikka ja skandaalin yhteiskunnallinen merkitys. Teoksessa: Väliverronen, Esa (toim.). Journalismi murroksessa. Helsinki: Gaudeamus, 262-284.

Jääsaari, Johanna (2004). YLE yleisön ehdoilla? YLE Yleisötutkimus, tutkimuksia 5/2004. Helsinki: Yleisradio.

Jääsaari, Johanna \& Savinen, Ari (1995). Television vaalikeskusteluohjelmat yleisön arvioitavina. Tutkimusraportti 2/1995. Helsinki: Yleisradio.

Kanerva, Jukka (1994). Ryvettymisen hyvä puoli: Suomalaisen politiikka ja poliitikot televisiossa. Jyväskylän yliopiston nykykulttuurin tutkimusyksikön julkaisu 40/1994. Jyväskylä: Jyväskylän yliopisto.

Kantola, Anu (2011a). Modernin julkisuuden teoria ja käytännöt. Teoksessa: Kantola, Anu (toim.). Hetken hallitsijat: Julkinen elämä notkeassa yhteiskunnassa. Helsinki: Gaudeamus, 17-41.

Kantola, Anu (2011b). Notkean journalismin nousu. Teoksessa: Kantola, Anu (toim.). Hetken hallitsijat: Julkinen elämä notkeassa yhteiskunnassa. Helsinki: Gaudeamus, 115-141.

Kantola, Anu (2011c). Liite 2: Vaalirahaskandaalin keskeisiä tapahtumia. Teoksessa: Kantola, Anu (toim.). Hetken hallitsijat: Julkinen elämä notkeassa yhteiskunnassa. Helsinki: Gaudeamus, 224-226.

Kantola, Anu \& Vesa, Juho (2011). Skandaalit ja julkinen elämä Suomessa. Teoksessa: Kantola, Anu (toim.). Hetken hallitsijat: Julkinen elämä notkeassa yhteiskunnassa. Helsinki: Gaudeamus, 42-64.

Kantola, Anu; Vesa, Juho \& Hakala, Salli (2011). Notkean myrskyn silmässä: vaalirahaskandaali. Teoksessa: Kantola, Anu (toim.). Hetken hallitsijat: Julkinen elämä notkeassa yhteiskunnassa. Helsinki: Gaudeamus, 65-88.

Karppinen, Kari \& Jääsaari, Johanna (2007). Suomalaisten käsityksiä mediasta ja vallasta. Raportti kyselytutkimuksesta. Helsinki: Helsingin yliopisto, Svenska social- och kommunalhögskolan, Forskningsinstitut. Saatavilla: http://sockom.helsinki.fi/fiss/suomi/teemaalueet/journalismi/valta/ raportti\%20271207.pdf (luettu 10.1.2012).

Kivikuru, Ullamaija (1996). Tasot eivät kohdanneet. Kansalainen ja media. Teoksessa: Kivikuru, Ullamaija (toim.). Kansa euromyllyssä. Helsinki: Helsinki University Press, 322-364.

Koski, Maija (2002). Kun poliitikot pudotettiin jalustalta - kansalaisnäkökulma politiikkaan vuosituhannen vaihteen Suomessa. Teoksessa: Kivikuru, Ullamaija (toim.). Laman julkisivut. Media, kansa ja eliitit 1990-Iuvun talouskriisissä. Helsinki: Palmenia-kustannus, 301-319.

Manin, Bernard (1997). The Principles of Representative Government. Cambridge: Cambridge University Press.

Mattila, Mikko \& Sundberg, Jan (2012). Vaalirahoitus ja vaalirahakohu. Teoksessa: Borg, Sami (toim.). Muutosvaalit 2011. Helsinki: Oikeusministeriö. Selvityksiä ja ohjeita 16/2012, 227-239. Saatavilla: http://www.vaalitutkimus.fi/documents/Muutosvaalit2011_finalversion20120319.pdf (luettu 31.3.2012).

McCombs, Maxwell (2004). Setting the agenda: The mass media and public opinion. Cambridge: Polity.

McNair, Brian (2003). An introduction to political communication. London: Routledge.

Moring, Tom \& Himmelstein, Hal (1993). Politiikkaa riisuttuna: Kampanjakulttuuri murroksessa televisioidun politiikan aikana. Tutkimusraportti 6/1993. Helsinki: Yleisradio.

Pietilä, Veikko (2002). Verkkokeskusteluareenat - deliberatiivista julkisuuttako? Politiikka 44: 4, 343354.

Rapeli, Lauri (2010). Tietääkö kansa? Kansalaisten politiikkatietämys teoreettisessa ja empiirisessä tarkastelussa. Annales Universitatis Turkuensis C296. Turku: Turun yliopisto. Saatavilla: http:// www.doria.fi/bitstream/handle/10024/59408/Annales_C_Lauri\%20Rapeli.pdf?sequence=3 (luettu 9.1.2012).

Ruonala, Katri-Mari (1998). Presidenttiehdokkaat televisiohaastattelussa. Teoksessa: Isotalus, Pekka (toim.). Kaveri vai peluri: Poliitikko mediassa. Jyväskylä: Atena, 38-68.

Saari, Heikki (2009). Median jahtaamat. Vantaa: Moreeni. 
Salokangas, Raimo (1996). Aikansa oloinen. Yleisradion historia 1949-1996. Helsinki: Yleisradio.

Suhonen, Pertti (2002). RISC-analyysi: Median kartta ja kompassi. Teoksessa Heikkilä, Heikki \& Helminen, Marjut (toim.). Journalismikritiikin vuosikirja 2002 (Tiedotustutkimus 25: 1), 152-161.

Virkkunen, Henna (2006). Ja ministeri erosi hymyillen. Teoksessa: Pernaa, Ville \& Pitkänen, Ville (toim.). Poliitikot taistelivat, media kertoo. Suomalaisen politiikan mediapelejä 1981-2006. Helsinki: Ajatus Kirjat, 127-158.

Väliverronen, Esa (2009). Journalismi kriisissä? Teoksessa: Väliverronen, Esa (toim.). Journalismi murroksessa. Helsinki: Gaudeamus, 13-31.

Väliverronen, Jari (2011). Kansalaisuus liikkeessä. Teoksessa Kantola, Anu (toim.). Hetken hallitsijat: Julkinen elämä notkeassa yhteiskunnassa. Helsinki: Gaudeamus, 142-163.

Väliverronen, Jari \& Kunelius, Risto (2009). Politiikan journalismi medioitumisen aikakaudella. Teoksessa: Väliverronen, Esa (toim.). Journalismi murroksessa. Helsinki: Gaudeamus, 225-247. 